\title{
POSTMODERN SUNSETS AND THE CONCEPT OF DEATH IN DELILLO'S WHITE NOISE AND ZERO $K^{\prime}$
}

\begin{abstract}
Throughout his works, Don DeLillo frequently refers to the concept of death and the fear of it. Death, as the ultimate ending of any life, is seen as a fearsome force in any form it takes in DeLillo's novels - be it war, terrorism, or overall destruction of civilization as we know it. In White Noise and Zero K, death is represented in the form of physical illness. The leitmotif of sunsets reoccurs in several of DeLillo's novels in relation to death, but most notably in these two. Strikingly similar, these phenomena are nonetheless regarded differently. The human interaction with these proves to be crucial for discussing the joy of living and the preciousness of human life.
\end{abstract}

Key words: Don DeLillo, death, society of terror, White Noise, Zero K

\section{Introduction}

Don DeLillo is generally regarded as an acclaimed contemporary writer whose literary worlds represent futuristic dystopias. Whilst dissecting the postmodern condition and the true nature of the media-driven, high-tech society that humans inhabit, he explores various topics. However, all these seem to be essentially related to the concept of death. Death reoccurs in his novels as a destructive force that is diametrically opposed to life and human existence. In this sense, the conflict between the binary life-death opposition can be said to be essential for DeLillo's novels. Each protagonist, dealing with different dilemmas and issues raised by modern and contemporary society, ultimately needs to face his or her inner struggle with the concept of death.

The conflict between binary oppositions is prominent in modern and postmodern literature. Binary oppositions, as pairings of fundamentally diametrically different concepts, seem essential to discussing any aspect of human existence, not only in

\footnotetext{
* PhD candidate, Faculty of Philosophy, University of Novi Sad, Dr Zorana Đinđića 2, 21000 Novi Sad, Serbia; e-mail: sladjana.stamenkovic@ff.uns.ac.rs

${ }^{1}$ This paper is done within the research for the project Language and Cultures in Time and Space, No. 178002, financed by the Ministry of Education, Science and Technological Development of the Republic of Serbia.
} 
literature, but also in sociology, philosophy, and other disciplines. In other words, human concepts have frequently been categorized in pairs of opposing, mutually confronted sides. Arguably, the most notable among these is the binary opposition between life and death. Given the fact that they can be translated to the opposition of existence and non-existence, this seems to be the question of utmost significance for humankind, and especially its philosophers and theoreticians. Thus, one should mark the famous observations of Socrates and Spinoza, among others, who consider death distinctively on the negative spectrum of the being-void opposition. Not only that, but they see death as meaningless, just an insignificant cessation of the body, as opposed to which we have the mind as a positive member of the opposition. This clear division between life and death is a predominant theme in the works of the $20^{\text {th }}$ century scholars. Baudrillard notes that "[f]rom Christianity to Marxism and existentialism: either death is openly denied and sublimated, or it is dialecticised" (Baudrillard 1993: 148). The opposition between life and death has been especially present in literary works from the very moment literature appeared. Bennett mentions the older legends in which "death is the punishment for the treachery or infidelity" (Bennett 2009: 66). Moreover, death also occurs as a punishment for personal tragic flaws in different mythological and literary characters. Icarus is burned because of his arrogance, Adam and Eve become mortal once they have fallen due to their forbidden curiosity, Hamlet dies for his indecisiveness and cruelty towards Ophelia, and so on. For all of them, death is distinctively a mechanism to show a flaw in character and to remove everyone who is not exclusively on the side of the Good.

The conflict between life and death in itself represents a conflict between existence and destruction. An epic clash between two opposing sides in which one is inherently positive and the other is inherently negative assigns life with being and death with emptiness. It resembles "the irreducible duality of the two pulsions, Eros and Thanatos [and] reawakens the ancient Manichean version of the world, the endless antagonism of the twin principles of good and evil" (Baudrillard 1993: 149). Meanwhile, literature stands on the outside, benefiting from the conflict, which gives it material for exploring the essential dilemmas of human existence. Blanchot and Davis note that literature is inherently related to death, since it is somewhat of a terrorist enterprise. Terrorist here does not have a connotation of terrorism, but of one that works by inflicting terror as an emotion onto others by means of their literary works or one that is prone to terror. Baudrillard also supports this when he writes about the "terroristic imagination that dwells in all of us" (Baudrillard 2002: 5).

Literature contemplates itself in revolution, it finds its justification in revolution, and if it has been called the Reign of Terror, this is because its 
ideal is indeed that moment in history, that moment when "life endures death and maintains itself in it" in order to gain from death the possibility of speaking and the truth of speech. (Blanchot and Davis 1948: 150)

Death, therefore, "becomes unavoidable, in some sense the desired lot of everyone, it appears as the very operation of freedom in free men" (Blanchot and Davis 1948: 149). It does not bring destruction alone, but also liberation, which is a sentiment characteristic of modernism and postmodernism. Baudrillard discusses Freud's influence on understanding and defining death, noting that, at that particular moment in history, it became regarded as "an indestructible principle" (Baudrillard 1993: 149). Concerning literature, specifically, Bennett assigns the clash between binary oppositions such as life-death to "contemporary legends." (Bennett 2009: xii). This term might as well refer to modern and postmodern literature. As May writes, the $20^{\text {th }}$ century brings a shift in attitude toward concepts that might be defined as sacred. Namely, since a person is confronted with something far more powerful, "a man's attitude is highly ambivalent: he neither moves easily toward the sacred nor casually away from it" but rather "experiences longing tempered by fear, and fear given to shy approach" (May 1972: 466). Blanchot's understanding of death is still somewhat divided. For him, it is a point of freedom, but also a point that is void of meaning in the modern world - a destiny that was about to be assigned to pretty much all aspects of human existence in DeLillo's fiction.

Death as an event no longer has any importance. During the Reign of Terror individuals die and it means nothing. In the famous words of Hegel, "It is thus the coldest and meanest of all deaths, with no more significance than cutting off a head of cabbage or swallowing a mouthful of water." Why? Isn't death the achievement of freedom - that is, the richest moment of meaning? But it is also only the empty point in that freedom, a manifestation of the fact that such a freedom is still abstract, ideal (literary), that it is only poverty and platitude. (Blanchot and Davis 1948: 149)

Despite such attitudes, death, for the philosophers and theoreticians of the $20^{\text {th }}$ century, was not only a natural course of life, but also access to a deeper meaning to life. That is, in their opinion, even though death might be void of meaning in itself, it still serves as a mechanism for achieving meaning and purpose, or at least of ascribing it to human life. In this manner, Kojève states that "[m]an gains access to God only after his death, and it is then alone that he realizes and fully manifests his "spirituality"' (Kojève 
1973: 35). Be it God, truth, the purpose of life or something similar, theoreticians respectively admit that death is essential to completing and complementing life, to giving meaning to it. Hegel's writing also corresponds to this approach, despite several implications of its potential lack of meaning. Kojève notes:

Acceptance without reserve of the fact of death, or of human finitude conscious of itself, is the ultimate source of all of Hegel's thought, which does no more than draw out all the consequences, even the most ultimate, of the existence of this fact. According to that thought, it is by voluntarily accepting the danger of death in a Struggle for pure prestige that Man appears for the first time in the natural World; and it is by resigning himself to death, by revealing it through his discourse, that Man arrives finally at absolute Knowledge or at Wisdom, in thus completing History. (Kojève 1973: 37)

Heidegger's philosophy further confirms such claims. His beliefs suggest that "to be human is indeed to be destined to live a life of only limited span" and that "human lives are indeed lives in which death plays a central role" (Malpas and Solomon 2002: 1). The critical point in such an approach is that "the significance of death is not to be found in the mere fact of the cessation of existence that is death itself, but rather in the relation between the fact of death and the possibilities for vital and fulfilled human life" (Malpas and Solomon 2002: 3). Yet, as Baudrillard states, even within philosophies that accept death as a natural element of life, "[it] serves as a tragic haunting of the subject, sealing its absurd liberty" (Baudrillard 1993: 149). The reason for such claims might lie in the fact that "[i]t is only in being-toward-death that the temporality of one's own being, and the historical-ontological context within which one's own being finds its ultimate sense, are disclosed" (Cohen 2006: 167). In other words, in bringing meaning and sense to human existence, death still serves as an indicator of how insignificant human life is, in the general plan of existence. Such different implications create a unique paradox that keeps following the concept of death in literature to this day. Namely, death is essential for life to have meaning, because it becomes more precious due to its temporariness. However, it is also an indicator that human existence is a passing category that cannot be compared to the existence of nature, for example. Precious and meaningless at the same time, death thus makes human existence paradoxical, as well. May writes of the two consequential responses to death, stemming from such interpretations, in the following paragraph:

The analysis so far has indicated two basic responses to the event of death in contemporary culture: on the one hand, the avoidance of death; on the 
other hand, a preoccupation with death as a destructive and catastrophic event. The category of the sacred explains their connection. Men are tempted simultaneously to conceal death and to hold themselves enthralled before it, because they recognize death as an overmastering power before which other responses seem unavailing. (May 1972: 470-471)

In other words, death poses itself as a dilemma of its own. Given that it implies meaning and the lack thereof simultaneously, it is a force that baffles people who, in response, do not know how to approach it. The lack of solid definition creates an atmosphere of obsession and terror. Meaningful or not, death still conceals what comes after, on which will depend whether it brings any meaning to life or not. The unknown aspect of death adds to the overall antagonization of death, resulting in meticulous undertakings to either understand it or to defeat it.

\section{Death and DeLillo's characters}

Death looms large over all DeLillo's novels. It figures as a prominent theme related to his protagonists in one way or another. In Cosmopolis, Erik Packer sets out on a day-long journey through New York only to rush to his own demise by the end of the novel. In Underworld, death appears as an ever-present, yet understated threat in the form of the hydrogen bomb that is referred to by various parties over and over, throughout the novel. In Point Omega, death appears as the sudden disappearance of human life when least expected, but also as the key motif of the video installation "24 Hour Psycho" that opens and closes the novel. Perhaps most notably, in The Body Artist, death and coping with death (i.e., the effect death has on the lives of those who remain after someone else dies) is explored through art and artistic expression. In every novel, DeLillo introduces death as a notion that is inherently negative for his protagonists, only to discover a more profound meaning not only to the concept of death, but also to the concept of life. In other words, his protagonists initially see death as a fearsome ending of their lives, a violent cessation of their existence that is the negative counterpart to being alive. However, as the novels progress, death becomes a more natural phenomenon in their eyes; one that is accepted and at some points, even necessary. Even when his main themes are concerned with modern phenomena, such as the media or technology, death appears as an underlying force driving, if not entirely, then at least partly, whichever action and event that takes place in the lives of his characters. For example, in White Noise, Jack Gladney is driven by his knowledge of his own approaching demise and his dedication to his family life and acceptance of life's strange ways and wonders is fueled almost solely by his newfound understanding of death. In The Body Artist, Lauren begins experimenting and creating her performance 
after the violent death of her husband. In Zero $K$, an undeniable shadow over Jeffrey's relationships and actions is his mother's death. Essentially, what his novels seem to suggest is a Heideggerian belief that one concept cannot exist without the other, and, what is more, that one concept does not have true meaning without the other.

While exploring ways in which people deal with death, DeLillo depicts different stages of death in his novels, such as a threat of it, mourning it, coping with the trauma of it, and so on. The concept of death also appears in different incarnations throughout his novels. Frequently, death is associated with aggression and violence; DeLillo's characters perceive it as a destructive outside force headed to destroy their lives or, in some cases, the entire world as they know it. May notes that for the characters of the $20^{\text {th }}$ century and later on, in general, "death is not interpreted merely as the biological incident that ends human life" but as a part of "all those destructive forces in the course of life that grip the heart with love, fear, hope, worry, and flight, long before the end is reached" (May 1972: 467). This statement suits DeLillo's characters perfectly. Most notably, in his novels, though, death is realized as either war and violence or illness and silent decay. In the case of the former, death is closely related to the issue of terrorism and the armed forces of different political beliefs. In the case of the latter, it is closely connected to the issue of ageism, but also modern medicine and science and, in it, technological development. The latter issue seems to be predominant in both White Noise and Zero K.

White Noise is DeLillo's ninth novel, first published in 1985. Its protagonist is Jack Gladney, a renowned professor of Hitler studies that lives in a small academic town with his wife Babette and children from several marriages. During an unfortunate toxic spill event in their proximity, Jack becomes exposed to a hazardous substance from a toxic cloud, at which point his obsession with his imminent demise starts influencing his actions and understanding of the world. Among other topics, the novel is frequently critically praised for discussing the notion of mass media and its influence on people's lives, as well as on popular culture. Zero K, on the other hand, is DeLillo's latest novel (at the point of writing this paper), published in 2016. It showcases a troubling story of the Lockhart family, once Ross and Artis Lockhart decide to submit to a cryogenic procedure of preserving their bodies for the future. The protagonist is Ross Lockhart's son from the first marriage Jeffrey and it is his point of view that allows the reader to experience this unique story. Although technology and medical advancement that might appear in the future are considered to be the main topics of these novels, death proves to be a robust underlying motif that brings about different dilemmas and troubles of the human experience. The problematic nature of death, especially one that comes as a result of illness, is evident in both novels. In White Noise, when Jack discusses his condition with his friend Murray, DeLillo explores 
what Murray proclaims to be "the nature of modern death" (DeLillo 2011: 175). In one particular passage from the novel, death seems like a terrifying force that man can never even fully grasp, let alone control.

It [death] has a life independent of us. It is growing in prestige and dimension. It has a sweep it never had before. We study it objectively. We can predict its appearance, trace its path in the body. We can take crosssection pictures of it, tape its tremors and waves. We've never been so close to it, so familiar with its habits and attitudes. We know it intimately. But it continues to grow, to acquire breadth and scope, new outlets, new passages and means. The more we learn, the more it grows. [...] Death adapts, like a viral agent. (DeLillo 2011: 175)

Death here appears as an intelligent entity, at times a strange, animal-like creature, or even a virus. Its interpretation, not only by Jack and Murray, but by people in general that they represent, suggests that it has a mind of its own. Moreover, its nature, mysterious and inexplicable, appears to them as difficult to grasp. These traits, as depicted in the novel, alienate the concept from humans and their lives, thus directly turning it into something inhuman, something that is far removed from natural human experience. Furthermore, the way its development and growing intelligence is described carries the ominous implication that it is out to get anyone it meets on its way. Its growth and innovative manners of operating mentioned in the previous passage strongly imply that its purpose might be directly turned against life and people just like Jack and Murray. Consequently, the representation creates an aversion and deep fear against the force that might destroy life as people know it. The two of them, much like the majority of Western civilization, regard the concept of death with primal fear and a semi-conscious reservation against it.

The common denominator for all issues surrounding the concept of death is the relationship between death and the society of terror, a concept thoroughly discussed in Baudrillard's writing. In short, the society of terror represents a modern society deeply rooted in simulacra whose inhabitants live in constant fear of an exterior destructive force. Terror here has less to do with the type of political system and extremist militant organizations and more with a genuine emotion of fear - one that is almost primal, and most definitely natural to humankind. DeLillo's America exists as what might be called a contemporary society of terror (although not all DeLillo's novels take place in the contemporary world) - a society that lives every day with an inseparable deep fear of, ultimately, death, but has no way of determining the specific cause of such fear. Rather than a cause-and-effect, it exists in people almost inherently, like a 
condition that is unavoidable in the modern world. Such fear of destruction and the end of existence often results in paranoia (collective and individual) which, in turn, constitutes a unique hyperreality where everyone primarily lives to escape death, more frequently than not on a subconscious level. The mechanisms for avoiding death range from consumerism, media frenzy and succumbing to celebrity and religious/spiritual cults to hectic adoption of technology in everyday life.

Yet, as Baudrillard suggests, such an attempt to avoid death only results in selfdestruction. He states that, as a rule, "[t]he system itself will commit suicide in response to the multiple challenges posed by deaths and suicides" (Baudrillard 2002: 17). The French theoretician here discusses terrorism as a sociological phenomenon. Mainly related to Baudrillard's notion of suicide, this phenomenon is associated with defying the dominant power and system by invoking the suicide of the system and, more importantly, its central ideology. The main idea suggests that a system has a tendency to commit suicide when faced with exterior destruction. However, on a smaller scale, this hypothesis works perfectly for DeLillo's characters in general. When faced with the challenge of outer destruction, they will all collectively turn to self-destruction, both literally and metaphorically. In Cosmopolis, Eric Packer will practically force himself into death while trying to escape the fear of his own demise (physical and financial). In Falling Man, Hammad joins the terrorist unit that is about to commit the 9/11 attack for different reasons, not the least significant of which is his fear of what his community might do to him if he tries to rebel against their commands. In Zero $K$, this is perhaps most evident in Artis, who practically commits suicide (because cryogenics, as depicted in the novel, does not really offer anything palpable beyond the procedure of preservation of the body) while trying to escape death by disease. One way or the other, as Baudrillard frequently notes, "death becomes simultaneously a "principle of psychical functioning' and the 'reality principle' of our social formations" (Baudrillard 1993: 148). This results in self-inflicted pain and destruction, which manifests not only as physical death, but also a death of interpersonal relationships and other utterly human social constructions.

\section{Death as a slow decay of the body}

In White Noise and Zero K, death reoccurs most notably in the form of illness (more or less terminal, and definitely incurable), among other forms. Death exists in DeLillo's protagonists silently; it is a part of them that they become increasingly aware of once diagnosed. In White Noise, Jack Gladney gets exposed to toxic substances from the Airborne Toxic Event relatively early in the novel. This exposure is said to have deadly consequences, although the reader is more saturated with the alleged consequences and their symptoms that the media starts proclaiming from the very 
minute the deadly cloud appears in the sky above Gladney's town. In Zero K, death and illness are more tangible, since the diagnosis is well-defined - Artis Martineu (Ross Lockhart's wife and the protagonist's stepmother) is at the terminal stage of several disabling diseases.

What is interesting about depicting a terminal illness and human reaction to it in these novels is that DeLillo explores such situations from different points of view. In both novels, the reader is presented with the inner mechanisms of coping with illness and accepting it from the position of either a patient protagonist or an observer protagonist. He also depicts human reactions to deadly diseases from both male and female points of view, as well as those that belong to different age groups. In White Noise, Jack is the main protagonist, a narrator and the patient. The reader is presented with a personal struggle with one's own demise from the very appearance of the disease. Other characters also offer their view of disease and death as outside parties - they are not patients but the family and friends of the terminally ill. However, DeLillo depicts their attitudes towards death even before Jack even becomes ill. In Zero $K$, Artis is neither the protagonist nor the narrator (with the exception of one short chapter which explores the state of her mind after the cryogenic procedure). Yet, her point of view is very well-depicted and clear, despite not being the main narrative focus of the novel. The reaction of her immediate family - her husband Ross and her stepson Jeffrey - offers an insight into the reaction and coping mechanisms of outside parties of different age groups.

What is common to each case is the fear that every protagonist feels when faced with death (their own or their loved one's). Moreover, fear is present in them even before they come face to face with the disease. For example, Jack and his wife Babette frequently discuss their respective fears and their reasons for wanting to die before the other one. Fear is the dominant sentiment when death is even mentioned among the protagonists, or at least it is so at first. The only point that is different from one case to another is the approach to death, specifically from the point of view of the patient, the one who faces death vis-a-vis. In other words, the difference exists in the things the patients do about their conditions. While one side reacts with acceptance, another chooses defiance. In White Noise, Jack starts dealing with his unnamed and vaguely defined condition somewhat aggressively, trying to determine his disease and potentially devise a plan to deal with the consequences. He also tries to, as Boxall puts it, "slow down" his life (Boxall 2006: 111); his insistence on focusing on small quotidian activities and matters can be seen as an attempt to postpone the moment of death, to hit the brakes and try to come closer to the deadly hour more slowly. When he refers to death, even before he finds out about his condition, he uses phrases such as "the terrible word" (DeLillo 2011: 87). However, he eventually accepts his faith 
and decides to live with his illness, waiting for it to start destroying him. He chooses to live in ignorance, refusing to do further testing on a regular basis to try and monitor the progress of his condition. By doing this, he not only refuses to act against death, but also refuses to try and foresee it.

On the other hand, Artis is determined to do everything she can about her disease. Her case of late-stage MS ultimately pushes her to enter a very aggressive cryogenic procedure in which her body is to be preserved under specific conditions while the cure for the deadly disease is found. Unlike Jack, who changes his opinion and approach, Artis sees her fight through - she voluntarily has her body frozen, despite the fact that no firm promise of a cure ever being found exists at that particular point. Her fight with death seems to be triumphant, because she manages to actually manipulate it, to postpone it. Yet, her fight against illness, and thus against death, is far less impressive once all the extreme aspects of the advanced medical procedure are revealed. Namely, her body is stripped of essentially all features that make her who she is. Her body (and the bodies of other patients) becomes but a shell - with no hair and, most importantly, with no head. The chapter that sees her after the procedure is an exploration of an afterlife, and a very sad one at that. She exists only through her language, which gets more confusing with each line, until her existence ends with no coherence, much like the chapter itself. Throughout the novel, Jeffrey refers to her as articulate and eloquent. Yet, in this chapter, her sentences are strange, fragmented and at times pointless. She eventually mentions that she is "all words but she doesn't know how to get out of words into being someone, being the person who knows the words" (DeLillo 2016: 157). The chapter ends with her implicit realization: "But am I who I was" (DeLillo 2016: 162). This suggests that, at least at some level, she is aware of her being less of a person. She is reduced to her ratio, which is doomed to deteriorate in "the pod", alienated from other people. Her approach to death and disease corresponds to what May names "the increasing subjection of the process of dying and death to rational, technical, specialized control" (May 1972: 468). It is a testimony to the human attempt to take control of both life and death. Unfortunately, what DeLillo seems to suggest in this case is that such attempts are disappointingly futile.

\section{Postmodern sunsets and death}

In both of these novels, and several others by DeLillo, a prominent leitmotif seemingly related to the concept of death is a sunset. Sunsets signify, in essence, an ending of a day, similarly to how death signifies an ending of life. Yet, sunsets are predominately seen as beautiful and romantic, and also, most importantly, perfectly natural - a part of the natural cycle that is accepted as necessary. Their connotation almost exclusively involves awe; sunsets are regarded as miracles of nature and the 
fact that they signify an ending is not even acknowledged, let alone negative. Death, on the other hand, is not associated with any positive, or even neutral, sentiment; particularly in Western civilization. It is regarded as an, if not unnatural, then definitely unwanted part of the life cycle. A clear parallel between these two is evident, but one of the main aspects that crucially differentiates them is time - a sunset ends something much shorter, as opposed to human death. A shorter duration directly contributes to less value being associated with the cycle that ends.

Furthermore, sunsets, as opposed to death, are quite well-defined - it is known what follows them and it is known that they do not bring the destruction of the world. Death, as uncharted territory, is by far more terminal on an individual level. A person can experience many sunsets, whereas death is, as far as we know, singular; it happens only once to a person. A great deal of this aspect has to do with uncertainty about what comes after it. Death brings an end similar to the one a sunset carries, but it offers no genuine promise of a new beginning. Considering that the period which ends with death is not only longer, but also more meaningful than the one that ends with a sunset, it is only logical that accepting it might come with a little bit more reluctance and fright.

Moreover, these two concepts are also related to the issue of human impact on nature. Both death and sunsets in White Noise and Zero K are corrupted - a testimony to the society DeLillo depicts in his novels. In both cases, human interference changing things for better or worse is highlighted, with a mostly negative environmental aftermath. Sunsets are corrupted by different chemicals and toxic spills in White Noise. Jack frequently refers to various industrial waste and radioactive substances that made sunsets different than they used to be; even when such statements are not directly related to the Airborne Toxic Event that takes place in his city. Simultaneously, death is violated by cryogenics and various other, less extreme, practices that are intended to postpone death, if not erase it altogether in Zero $K$. What is more, death of nature as such due to human impact reoccurs throughout DeLillo's novels. Such is the case with, for example, Underworld and endless mountains of waste, among others. Considering sunsets, their corruption is a consequence, rather than a conscious enterprise. Namely, people did not attempt to change the nature of sunsets, modify them or stop them. These corrupted "postmodern sunsets" (DeLillo 2011: 260) are rather a byproduct of a human attempt at conquering and modifying nature and the world around them. As Knight writes, these postmodern sunsets, as Jack calls them, are "a product not of pure nature but of the frightening causal networks of pollution, risk, and industrial hazard that defy our rational powers of prediction or comprehension" (Knight 2008: 38). As a result, the sunsets became "unbearably beautiful"; they took an "aesthetic leap from already brilliant sunsets to broad towering ruddled visionary skyscapes, tinged with 
dread" (DeLillo 2011: 197). As opposed to that, death is the direct object of attempted modifications. The end results can be seen as diametrically opposed - while sunsets remain beautiful even when corrupted, death becomes something even more monstrous than it originally was. Such monstrosity is reflected in the unnatural subversion of death by modern technology and trends, which in turn make death appear as something even stronger and ominous to people who perceive it. For Jeffrey, death becomes a much more frightening notion once his father and stepmother begin discussing the cryogenics procedure. Artis and Ross's voluntary cryogenic preservation resembles a self-induced death more than a successful conquering of the secret of eternal (or at least prolonged) life. The aforementioned chapter that sees Artis after the procedure seemingly proves this point. A woman who was, above all, characterized by her eloquence and intelligence becomes reduced to incoherent blabbering, unable to do anything by her own will until the so-called scientists decide to make her body functional again. The chapter that offers a glimpse into her existence after the procedure consists of different sentences, all in the form of statements, even when they are evidently meant to be questions. The narration switches from the first to third person, as if she tries to offer her direct experience and to narrate herself into coherent existence, at the same time. In the final line of the chapter, she refers to herself as a "woman's body in a pod" (DeLillo 2016: 162). Contrastively, her language before this procedure is a bit on the formal, well-educated side. She refuses to use nicknames and calls Jeffrey by his full name. She discusses complex, philosophical questions both presently and in retrospective episodes, offered to the reader by Ross and Jeffrey. The decline in eloquence and coherence is evident, and it seems to serve as a means of exposing the procedure as something inherently negative.

Sunsets, generally, are deeply connected with the passage of time in DeLillo's writing, as well. For example, when Jeffrey reminisces about his mother Madeline, he says "[t]ime is passing, the sun is setting, the person is waiting, I am waiting" (DeLillo 2016: 102). Sunsets here operate as indicators of time passage, used to highlight the agony of human existence. Another time he mentions "the sun beginning to sink" is when he discusses the gloominess of human life with his father, who is rapidly sinking into depression (DeLillo 2016: 131). This way, sunsets carry more than just a romantic connotation in DeLillo's novels - they are used to stress the fact that nature moves on, continues to live through its natural cycles regardless of the torment that people might experience in the meantime. As Boxall notes in the following passage, sunsets in White Noise are especially connected to temporality:

Death, the second coming, the end of history, these release us into a form of endless continuation, an immaterial, despatialised temporality. [...] The 
sunset - that livid, 'violet' moment that throbs, for T.S. Eliot, 'between two lives' marking the space of the end and the space of transition - the sunset expands in White Noise, stretches and yawns, threatening to engulf the entire novel in its timeless time, the empty time in which everything is already familiar, and yet nothing is quite itself. It is as the sunsets crank up their millennial immediacy, [...] that they begin to elongate, and to distend. 'Sunsets used to last five minutes,' Babette says to Jack in her Kierkegaardian fear and trembling, 'now they last an hour' (WN 170). (Boxall 2006: 112-113)

What Boxall seems to suggest here is that these elongated sunsets in White Noise resemble some limbo, where the natural cycle is prolonged beyond its natural affinity. The temporality of human life, much like anything else in nature, is regarded as negative. Perhaps this is why it is peculiar that it is only after certain modifications (caused directly by the human factor), that sunsets become longer and more stretched out. Parallel to this, death in Zero $K$ becomes prolonged on its own. It seems that, when faced with the temporality of life and existence, DeLillo's characters initially respond by resisting it, or at least trying to do so. In true postmodern fashion, they try to subvert the phenomena that surround them, both accidentally and deliberately. Sunsets may well be prolonged by pure chance in White Noise (given that the toxic spill was not an intentional incident), but death (or rather the moment of death) is postponed by firm intention.

Concerning the very expression postmodern sunsets, Knight defines their postmodern nature related to the fact that their "spectacular, lurid colors are a result not of natural, organic splendor but of the "airborne toxic event" that is affecting the weather" (Knight 2008: 28). Moreover, their postmodern quality comes from them being "self-consciously "postmodern" because [they are] merely a shorthand copy of endless descriptions of other sunsets that have become a literary cliché" (Knight 2008: 28). Knight's comments suggest that the postmodern aspect of the sunsets in White Noise is primarily associated with their artificial nature. Such artificial nature might come from the literal interference of artificial substances, but also from the more metaphorical relation to the cliché representation of romantic sunsets in American popular culture, mainly Hollywood movies. Similarly, Frow's assessment of this issue corresponds to Knight's; he states that as "[p]ostmodern writing always comes after, the postmodern sunset is another sunset, an event within a series, never an originating moment but mass-produced as much by the cosmological system as by the system of writing" (Frow 1990: 35). Both scholars strongly suggest that postmodernity in DeLillo's sunsets comes primarily from their simulated nature. Their present state and 
especially representation are inseparable from their counterpart spectacle present in the mass media. In other words, the actual sunsets cannot exist within the conscience of people who experience them without the mental image of the mass media version of sunsets. In a similar manner, death might also be denominated as "postmodern" in DeLillo's America, since it too is but another reproduction of a vast array of other deaths that happened beforehand. In other words, in a culture that has already represented everything on film and television, it is difficult to expect even death (and the hour of dying) to be original. This argument may best be seen in other DeLillo's novels, such as Cosmopolis, where Eric Packer only imitates movie stars in his final hours, or The Body Artist, where Lauren Hartke's husband commits suicide "off the camera", much as it sometimes happens in the movies. Perhaps even more gloomily, this corruption and postmodernity of natural cycles of existence by the human element and their subsequent results connect both death and sunsets to the concept of spectacle. Primarily related to the mass media, a spectacle is an exaggerated version of an event, whether it is a news report, a show, a performance or a sports match. For an event to be classified as a spectacle, it needs to be new, innovative, shocking and entertaining, preferably all at once. At the same time, spectacles are also burdened by cliché representations and plots, and are a part of mass-produced popular culture.

To some extent, both death and sunsets function as spectacles in these novels. Sunsets perhaps correspond to this interpretation more than death, in so far as they represent an already beautiful and amazing event, which is modified by people (albeit unintentionally) to become even more beautiful and more mesmerizing. Although this "enhanced" quality primarily functions as DeLillo's means to subtly comment on the culture of spectacles, it nevertheless implies that the visible beauty and attractiveness of sunsets are not tarnished by the modifications they underwent. Not only this, but typically for DeLillo, they become more attractive in terms of marketing, as their popularity drives people to go out to see them, experience them as a show or a performance, or even photograph them. Death, on the other hand, becomes a spectacle that resembles more contemporary performance as an art form. Artis' experience after the procedure seems experimental, an exploration of human language and mindset free of the corporal, physical aspect. Her surrender to the procedure contains a dramatic quality, which, combined with her afterlife episode that sounds like an experimental art performance, shapes her story as a melodramatic spectacle. Moreover, the fact that the clinic is not an exclusively scientific institution makes the entire enterprise seem more a spectacle than anything else. The Convergence is, above all, a spiritual group, a sect or a faction. Their activities are not solely focused on the scientific aspect of preserving the body and helping patients be cured. A much larger share of their activities includes a dogmatic induction into a system where becoming a human shell, frozen in their 
facility is a joint venture that expresses a set of beliefs - one perhaps intended to shock and affect the outside world that sees them (in person or in the media). This is precisely why Artis' death holds no value. It corresponds with Blanchot's belief that "when freedom is an absolute apparition, dying is unimportant and death has no depth" (Blanchot and Davis 1948: 149). Artis' freedom is questionable because the extent of the dogmatic influence that the Convergence has over her is not entirely clear. The possibility (and a high one at that) of the entire enterprise being just a staged performance by the leaders of the group undermines her actions and freedom of choice, making her a mere spectacle of the spectacle machinery.

Furthermore, the Convergence, to some extent, manages to rob Artis and Ross of their natural right - that of natural death - a defining moment that gives meaning to the entire prior existence of the person. Not necessarily a spectacle per se, their joint surrender to cryogenics is somewhat similar to the mass wedding from Mao II. ${ }^{2}$ It is performed under the influence of a belief group, more as a performance that serves a general purpose than a true act of practicing one's own beliefs and liberties. Blanchot and Davis discuss this problematic aspect of a religious (spiritual or otherwise related to a cult) context of avoiding death by invoking Heideggerian ideas about the "humanity" of immortality:

Certain religions have taken the impossibility of death and called it immortality. That is, they have tried to "humanize" the very event which signifies "I cease to be a man". But it is only the opposite thrust that makes death impossible: through death I lose the advantage of being mortal, because I lose the possibility of being man; to be man beyond death could only have this strange meaning - to be, in spite of death, still capable of dying, to go on as though nothing had happened, with death as a horizon and the same hope - death which would have no outcome beyond a "go on as though nothing had happened". (Blanchot and Davis 1948: 161)

In this sense, the corrupted nature of death (by dogmatic influences) results in people being robbed of their essential humanity. In other words, everything that

\footnotetext{
${ }^{2}$ Mao II is DeLillo's novel published in 1991. Focusing on the nature of masses and possible manipulation of such social structures, the mentioned episode refers to the organized mass wedding of female American followers of the cult and selected male followers from different parts of the world, mainly Asia. DeLillo describes people's unquestioning surrender to prearranged marriages as a joint trans-like state, since the participants do not really think their decisions through, but follow the instructions of the cult blindly and devotedly. The same can be said for the corresponding episode in Zero K, when Ross and Artis accept all the arguments of the Convergence in favor of the procedure without focusing on their, sometimes obvious, frail reasoning and questionable motives.
} 
essentially means being a human is thus spoiled by dogmatic ideas of an afterlife. Although Artis is officially only frozen, it is a form of life only nominally. Her existence in the abyss that comes after the procedure affects and diminishes her prior existence as a person. Not only does it put her in a problematic position in the present time, but it also corrupts everything that she was as a person. Artis the Archeologist becomes Artis the "body in a pod" (DeLillo 2016: 162). This is not the first instance when she refers to herself as a body. Yet, on the previous occasion, when she discusses herself as "the body in the shower" (DeLillo 2016: 162), she manages to discuss the complex notion of time and temporality on an almost professional philosophical level. Once she undergoes the procedure, she becomes incapable of expressing herself, despite her being "all words" (DeLillo 2016: 157). The fact that an intelligent person succumbed to a shady cult only in an attempt to avoid death is a sad testament to humanity's futile attempt to control the uncontrollable, in which process they lose the meaning and purpose that the natural course was supposed to bring.

\section{Accepting death in White Noise and Zero K}

What is interesting is the fact that ultimately, in both White Noise and Zero $K$, death is accepted as a natural course of life by the respective protagonists of the novels. It should be stated that only one of the protagonists in these novels - Jack is personally overtly threatened by death, since Jeffrey is not only young, but also perfectly healthy. Yet, the concluding scenes, both of which symbolically involve enjoying the sight of a (postmodern) sunset, do bring a peaceful acceptance of death as a natural part of life - not an enemy or a destructive outside force that life faces in an epic fight between the Good and the Evil, but something that is inseparably connected to life itself; not an opposition, but a partner, in a way. Both Jack and Jeffrey begin to truly see the small wonders of life only after they come face to face with death and its implications. The concept of death thus complements the concept of life, by shining light on its most beautiful and valuable aspects. Hence, they achieve what Heidegger would see as "an appropriate understanding of death for a proper understanding of human life and for the proper living of such a life" (Malpas and Solomon 2002: 3). As stated, Jack decides to await the development of his disease calmly, spending time with his family and immersing himself in everyday life. Jeffrey walks away from the Convergence (after his father finally decides that he has to follow Artis and submit himself to the procedure) and, despite a fleeting doubt in his own beliefs, dismisses the value that such attempts at controlling life and death might have.

However, in a move typical for the writer, not everything ends on a completely positive note. Indeed, death is accepted as natural by the protagonists, but this acceptance occurs exclusively on the individual level, as in other DeLillo's novels. 
The revelation, unfortunately, takes place on the micro-level - only occasionally does a person become at peace with their death and the fear of it; the masses, however, do not stray from their course - they keep trying to avoid it.

In White Noise, Jack accepts his death, but Babette and their children, as well as friends, still see it as something terrifying that they would rather avoid. The outside world is not affected by his revelation, not that Jack makes any move to persuade anyone to adopt his newfound beliefs. In Zero $K$, the Convergence continues to exist and, what is more, the protagonist's father, Ross Lockhart, a perfectly healthy man who still has quite a few good years ahead of him, voluntarily enters this program. In other words, not only does the absurd organization keep working with the sick, but it also starts including perfectly healthy people. Such a development is in accordance with what Baudrillard observes in Western civilization; namely, that "the West [...] has become suicidal and declared war on itself" (Baudrillard 2002: 7). Here, we have an individual declaration of war on oneself, driven by the numbing fear of death that one cannot control. What DeLillo seems to suggest in both novels is that a deeper understanding of the concept of life, with death as its inseparable part is, in the modern world so far at least, possible only at an individual level - to rare people who are able to face their fears and focus on finding real meaning in life while they are alive, rather than pondering over what could happen after they die. On a general level, however, human civilization (more precisely Western civilization at that) is not yet prepared to ascend to this higher level of understanding.

\section{Conclusion}

Death, for both protagonists, represents a necessary ending that would ultimately define the entire life or story of one's life. In this way, death does not become only inevitable, it becomes essential, crucial to one's life. As Blanchot and Davis both note, "everything would sink into absurdity and nothingness" if there were no death (Blanchot and Davis 1948: 152) and DeLillo's protagonists both imply this by the end of each novel. To have a purpose and to make sense, a life needs an ending. As Jack notices in White Noise, "all plots tend to move deathward" (DeLillo 2011: 26). In other words, everything that lives and exists naturally navigates toward its own ending. Dynamics, or "plots" as he calls them, imply ceasing; everything that moves must eventually stop. For this reason, death is seen as some type of a natural wonder, or even a miracle by both Jack and Jeffrey in the closing scenes of their respective novels.

Another natural wonder that merits the epithet of a miracle in both novels is the sunset. Jack looks at the colorful sky at sunset (under the influence of various chemicals) and stands mesmerized by the power of nature and people. Jeffrey stands 
mesmerized by the reaction of a little boy on the bus during Manhattanhenge - a sunset where the sun is perfectly aligned with the streets of New York. Both are inspired to focus more on the pure joy of living, and to seek to enjoy the little joys of living in their everyday life.

As in front of death, the people who join Jack, Babette and Wilder to watch the sun set are mostly dumbfounded. Jack observes that "some people are scared by the sunsets, some determined to be elated, but most of [them] don't know how to feel, are ready to go either way" (DeLillo 2011:373). What is also interesting is their collective feeling of awe, "it is all awe, it transcends previous categories of awe", despite the fact that they "don't know whether [they] are watching in wonder or dread" and that they are not entirely certain what exactly they are watching, a permanent phenomenon or a temporary distortion of nature (DeLillo 2011: 373). Yet, despite the implied dread that some of them perceive, sunsets, as well as death, can be admired as an impressive phenomenon characteristic and essential for the human experience.

Jeffrey, on the other hand, is focused on the pure joy of watching a sunset, thanks to a little boy mesmerized by the natural phenomenon. In the closing paragraphs of the novel, he notes that he is "startled by a human wail" and he focuses on "the boy on his feet, facing the rear window [...] pointing and wailing at the flaring sun, which was balanced with uncanny precision between rows of high-rise buildings" (DeLillo 2016: 273). No dread seems to be implied in his experience, whether as a result of his young age or a higher level of understanding life, which remains a mystery. The ending lines of this novel seem to convey a definite dismissal of both fear of death and the desperate need for an afterlife.

The full solar disk, bleeding into the streets, lighting up the towers to either side of us, and I told myself that the boy was not seeing the sky collapse upon us but was finding the purest astonishment in the intimate touch of earth and sun.

I went back to my seat and faced forward. I didn't need heaven's light. I had the boy's cries of wonder. (DeLillo 2016: 274).

While experiencing the most clichéd ending of them all - riding off into the sunset - Jeffrey summarizes the conclusion both him and Jack Gladney reach within their respective novels. Miracles and small wonders of living can only be truly perceived and cherished once one comes to terms with an imminent ending of existence. A genuine acceptance of death as a natural part of the course of life enables both protagonists to embrace their everyday joys and all truly meaningful fragments of their life. 


\section{References}

Baudrillard, J. (1993). Symbolic Exchange and Death. London: Sage Publications.

Baudrillard, J. (2002). The Spirit of Terrorism. London: Verso.

Bennett, G. (2009). Bodies: Sex, Violence, Disease, and Death in Contemporary Legend. Jackson: University Press of Mississippi.

Blanchot, M. and L. Davis (1948). Literature and the Right to Death. In: D. K. Keenan (ed.), Hegel and Contemporary Continental Philosophy, New York: State University of New York Press, 135-166.

Boxall, P. (2006). Don Delillo: The Possibility of Fiction. London: Routledge.

Cohen, R. A. (2006). Levinas: Thinking Least about Death — Contra Heidegger. In: E. T. Long (ed.), Self and Other: Essays in Continental Philosophy of Religion, Dordrecht: Springer, 21-39.

DeLillo, D. (2011). White Noise. London: Picador.

DeLillo, D. (2016). Zero K: A Novel. New York: Scribner.

Frow, J. A. (1990). The Last Things Before the Last: Notes on White Noise. South Atlantic Quarterly, 89(2), 413-430.

Knight, P. (2008). DeLillo, Postmodernism, Postmodernity. In: J. Duvall (ed.), The Cambridge Companion to Don DeLillo, New York: Cambridge University Press, 27-40.

Kojève, A. (1973). The Idea of Death in the Philosophy of Hegel. In: D. K. Keenan (ed.), Hegel and Contemporary Continental Philosophy, Albany: State University of New York Press, 27-74.

Malpas, J. E. and R. C. Solomon (2002). Death and Philosophy. London: Routledge. May, W. F. (1972). The Sacral Power of Death in Contemporary Experience. Social Research, 39(3), 463-488. 